\title{
Review
}

Journal of Innate

Immunity
J Innate Immun 2015;7:333-339

DOI: 10.1159/000371423
Received: November 4, 2014

Accepted after revision: December 8, 2014

Published online: February 6, 2015

\section{C4a: An Anaphylatoxin in Name Only}

\author{
Scott R. Barnum \\ Departments of Microbiology and Neurobiology, University of Alabama at Birmingham, Birmingham, Ala., USA
}

\section{Key Words}

Anaphylatoxin $\cdot$ Complement $\cdot G$-protein-coupled receptors

\begin{abstract}
Activation of complement leads to generation of the 3 anaphylatoxins $\mathrm{C} 3 \mathrm{a}, \mathrm{C} 4 \mathrm{a}$, and $\mathrm{C} 5 \mathrm{a}$. Although all 3 peptides are structurally similar, only $\mathrm{C} 3 \mathrm{a}$ and $\mathrm{C} 5 \mathrm{a}$ share a similar functional profile that includes the classic inflammatory activities and, more recently, developmental homing and regenerative properties among others. In contrast, the functional profile of $\mathrm{C} 4 \mathrm{a}$ is questionable in most cases owing to contamination of $\mathrm{C} 4 \mathrm{a}$ preparations with physiologically relevant levels of C3a and/or C5a. Combined with the absence of an identified $\mathrm{C} 4 \mathrm{a}$ receptor and the inability of $\mathrm{C} 4 \mathrm{a}$ to signal through the C3a and C5a receptors, it is clear that C4a should not be included in the family of complement anaphylatoxins.
\end{abstract}

(c) 2015 S. Karger AG, Basel

The complement system is composed of over 40 soluble proteins and membrane receptors and is well known for its role in initiating and modulating innate and adaptive immune responses to a wide variety of pathogens. In the last 10-20 years it has become clear that complement also contributes to many facets of biology well beyond pathogen elimination. For example, it is now established that several complement components are critical in tissue turnover, the development of bone and cartilage, liver regeneration, and homing of hematopoietic stem cells and neural progenitor cells [reviewed in 1-4]. Furthermore, recent studies have demonstrated that 2 central components of the complement system, i.e. C3 and C5, are important in limb and eye regeneration after injury [5], while C1, C3, and the complement receptor type 3 contribute to synaptic pruning in development and disease [6]. Complement even exerts psychopharmacological control on eating and drinking behavior based on studies in rodents [7-12]. C3a and C5a, 2 polypeptides derived from proteolytic cleavage of $\mathrm{C} 3$ and $\mathrm{C} 5$, respectively, mediate a significant number of the biological activities listed above. Collectively, C3a and C5a, along with $\mathrm{C} 4 \mathrm{a}$, a third polypeptide derived from cleavage of $\mathrm{C} 4$, are known as anaphylatoxins because of their ability to induce a variety of inflammatory responses which can be as severe as type I hypersensitivity allergic responses $[3,13]$. Although all 3 proteins are labeled anaphylatoxins, there is remarkably little evidence to support a role for C4a in this capacity. In this review, the case for removing C4a from the list of complement anaphylatoxins is made based on its limited range of biological activities and the absence of a specific $\mathrm{C} 4 \mathrm{a}$ receptor to mediate these functions.

\section{The Anaphylatoxins}

\section{Structure}

The complement anaphylatoxins are derived from cleavage of the a-chain of C3, C4, or C5 on activation of complement through the classic, lectin, alternative, or

\section{KARGER 125}

(c) 2015 S. Karger AG, Base

$1662-811 \mathrm{X} / 15 / 0074-0333 \$ 39.50 / 0$

E-Mail karger@karger.com

www.karger.com/jin
Dr. Scott R. Barnum

Department of Microbiology, University of Alabama at Birmingham 845 19th St. S. BBRB/842

Birmingham, AL 35294 (USA)

E-Mail sbarnum@uab.edu 
Table 1. Complement anaphylatoxin functions

\begin{tabular}{|c|c|c|c|c|}
\hline Function & $\mathrm{C} 3 \mathrm{a}$ & $\mathrm{C} 4 \mathrm{a}$ & $\mathrm{C} 5 \mathrm{a}$ & Reference \\
\hline Defined receptor & + & - & + & $3,4,29-31$ \\
\hline Chemotaxis & + & $?$ & + & $3,4,13,32,33$ \\
\hline Smooth-muscle contraction & + & $?$ & & $3,4,13,34$ \\
\hline Vascular permeability & + & $?$ & + & 34,35 \\
\hline Myeloid cell activation & + & - & + & $3,4,13,36$ \\
\hline Platelet activation & + & - & + & $3,4,13,37,38$ \\
\hline $\mathrm{CD} 4 / \mathrm{CD} 8$ and $\gamma \delta \mathrm{T}$ cell modulation & + & - & + & $39-44$ \\
\hline Induction of acute phase response (cytokine production) & + & - & + & $3,4,13,45$ \\
\hline Developmental homing & + & - & + & $46-49$ \\
\hline Regeneration & + & - & + & $1,2,50,51$ \\
\hline Antimicrobial & + & + & - & $27,52-54$ \\
\hline Cross-desensitization & & $?$ & & 55,56 \\
\hline
\end{tabular}

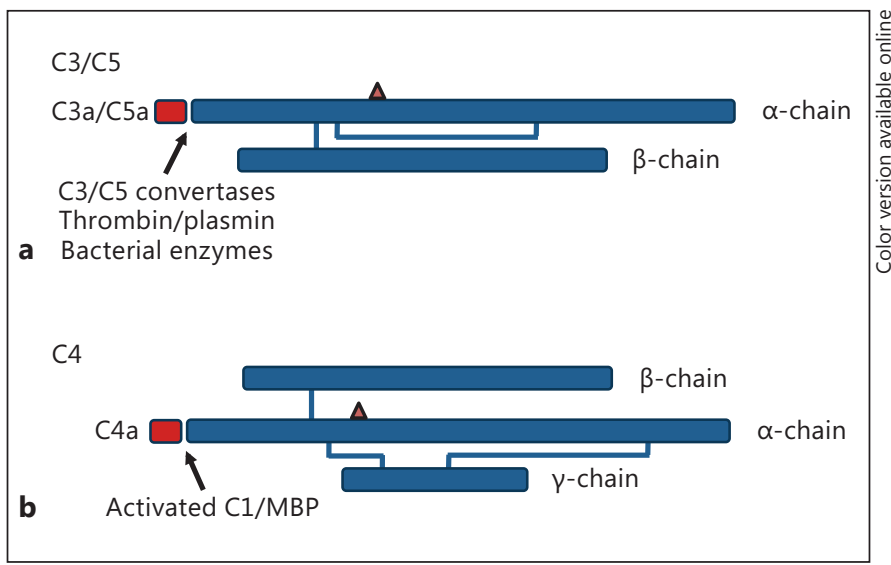

Fig. 1. Schematic of the polypeptide structure of human $\mathrm{C} 3, \mathrm{C} 4$, and C5. a C3 and C5 are composed of an $\alpha$ - and a $\beta$-chain that have inter- and intrachain disulfide bridges. $\mathrm{C} 3 \mathrm{a}$ and $\mathrm{C} 5 \mathrm{a}$ are derived by cleavage of the amino-terminal end of the $\alpha$-chain by $\mathrm{C} 3 / \mathrm{C} 5$ convertases, activated coagulation proteases including thrombin, plas$\mathrm{min}$, and factors IX through XI, and by bacterial enzymes. b C4 is composed of 3 polypeptide chains $(\alpha, \beta$, and $\gamma$ ) which also have inter- and intrachain disulfide bridges. $\mathrm{C} 4 \mathrm{a}$ is derived by cleavage of the amino-terminal end of the $\alpha$-chain by activated $\mathrm{C} 1$ on activation of the classical, or by activated mannose binding protein on activation of the lectin pathway. The triangle indicates the relative position of the thioester bond found in the $\alpha$-chain of $\mathrm{C} 3$ and $\mathrm{C} 4$.

extrinsic protease pathways or by one of several bacterial enzymes [reviewed in 3] (fig. 1). The 3 proteins have a molecular weight of approximately $9 \mathrm{kD}$ and range in size from 74 to 77 amino acids. C5a is posttranslationally modified with a single complex carbohydrate chain attached through an $\mathrm{N}$-linked glycosidic bond to asparagine residue 64 [14], while C3a and C4a have no car- bohydrate side chains and lack the classic Asn-X-Ser/ Thr glycosylation site motif. Despite similar biological functions, particularly for C3a and C5a (discussed below), there is limited sequence homology between the human anaphylatoxins. All 3 proteins have 6 invariant cysteine residues that give rise to a 4-helix core generated by 3 disulfide linkages [15-17], a limited number of conserved residue substitutions, and a carboxy-terminal arginine residue $[14,18,19]$. The sequence homology of the anaphylatoxins is high between species (as much as 70\%) [3, 20-22], but it is considerably lower between the human proteins. For example, human C3a shares only 29 and 34\% identity with C4a and C5a, respectively, a level of homology comparable to that between the entire coding sequence of $\mathrm{C} 3, \mathrm{C} 4$, and $\mathrm{C} 5$ [23]. The proteins share higher-order structural features, including backbone architecture, 4 antiparallel helices, and an overall compact globular shape, while the amino- and carboxy-terminal regions have no ordered conformation [24-28].

\section{Function}

Despite the structural similarity between the complement anaphylatoxins, the functional profile of these proteins is dramatically different with respect to C4a. As outlined in table 1, C3a and C5a share an amazing array of diverse functional properties that includes modulation of the innate and adaptive immune response, cell homing, and tissue regeneration. In contrast, $\mathrm{C} 4 \mathrm{a}$ mediates almost none of these functions and, in those cases where a functional overlap is reported, closer inspection of the data suggests a significant weakness in the studies. The fundamental problem in most cases is the purity of the $\mathrm{C} 4 \mathrm{a}$ 
preparations. For example, the initial studies identifying $\mathrm{C} 4 \mathrm{a}$ as an anaphylatoxin were performed using human $\mathrm{C} 4 \mathrm{a}$ in a guinea pig ileum contraction assay. C4a could induce ileum smooth muscle contraction but at concentrations $\sim 100$-fold higher than those used for C3a [34]. Furthermore, C4a induced erythema and wheal formation upon injection into the skin of human volunteers, but again concentrations several orders of magnitude higher were required to elicit the same response via injection of C3a and C5a. The C4a preparations used in these studies were contaminated with physiologically relevant levels of C3a $(0.002 \%)$ and C5a $(0.006 \%)$, suggesting that the biological activity attributed to C4a was in fact due almost entirely to C3a/C5a [34]. Given that C3a and C5a are functional in the nanogram range, this level of contamination (due most likely to the biochemical preparatory methods employed) would be sufficient to induce the reported biological responses. A subsequent study examining the ability of the anaphylatoxins to cross-desensitize guinea pig platelets revealed that C4a had only $3 \%$ of the activity of C3a on a molar basis [38]. Given that the C4 used in the study was prepared in exactly the same way as in the study of Gorski et al. [34], it is clear that C3a and $\mathrm{C} 5 \mathrm{a}$ contamination complicates the interpretation of the reported results. More recently it was reported that $\mathrm{C} 4 \mathrm{a}$ induced $\mathrm{Ca}^{++}$mobilization in guinea pig macrophages and that these cells were still sensitive to C3a-mediated $\mathrm{Ca}^{++}$mobilization, suggesting that $\mathrm{C} 4 \mathrm{a}$ has its own receptor [56]. The authors did not, however, assess for trace amounts of C3a and C5a in the C4a used in the study, which had been prepared using a method similar to that of Gorski et al. [34], raising concerns about the purity of $\mathrm{C} 4 \mathrm{a}$ and the validity of the data. In a study using recombinant $\mathrm{C} 4 \mathrm{a}$ and $\mathrm{C} 5 \mathrm{a}$ (thus overcoming the contamination issue), the ability of $\mathrm{C} 4 \mathrm{a}$ to inhibit $\mathrm{C} 5 \mathrm{a}$-mediated neointima injury was assessed [55]. Coinfusion of C4a and C5a resulted in reduced neointima formation relative to infusion of $\mathrm{C} 5 \mathrm{a}$ alone. However, interpretation of the data is complicated by the fact that dose-response experiments were not performed and the amount of both anaphylatoxins administered to mice was exceedingly high (0.1 mM) relative to physiological levels. Finally, in a study proposing a new function for $\mathrm{C} 4 \mathrm{a}$, the ability to inhibit blood monocyte chemotaxis, possible $\mathrm{C} 3 \mathrm{a} / \mathrm{C} 5 \mathrm{a}$ contamination, and the ill-defined components of zymosan-activated serum significantly weakened the interpretation of the results [32].

For many of the biological activities listed in table 1, such as developmental homing or tissue regeneration, $\mathrm{C} 4 \mathrm{a}$ has yet to be assessed relative to C3a and C5a. Thus it cannot be ruled out that $\mathrm{C} 4 \mathrm{a}$ shares no functional overlap with the other anaphylatoxins. In fact, C4a and C3a both share antimicrobial activity toward Gram-negative and Gram-positive bacteria based on studies using purified proteins and 20-mer peptides derived from the sequence of various regions of both peptides $[27,53]$. It should be noted however, that C3a/C4a antimicrobial activity is receptor independent, relying instead on the overall net charge, percentage of hydrophobic amino acids, and degree of amphipathicity of the peptides [57]. Nevertheless, it is striking that the C4a biological activity is so limited relative to that of $\mathrm{C} 3 \mathrm{a}$ and $\mathrm{C} 5 \mathrm{a}$. Although it is possible that $\mathrm{C} 4$ a contributes to $\mathrm{C} 3 \mathrm{a} / \mathrm{C} 5 \mathrm{a}$-mediated immune functions, until more rigorous studies are performed, the in vitro and in vivo data to date fails to support its moniker as an anaphylatoxin.

\section{The Anaphylatoxin Receptors}

Perhaps the most compelling argument that $\mathrm{C} 4 \mathrm{a}$ is not an anaphylatoxin is the absence of an identified C4a-specific receptor and the inability of $\mathrm{C} 4$ a to effectively signal through any known human receptor. To date, a single $\mathrm{C} 3 \mathrm{aR}$ and $2 \mathrm{C} 5 \mathrm{aR}$ (C5aR1 and C5aR2) have been characterized in humans and many other species (fig. 2) [30, 31, 58-60], all of which are members of the large G-proteincoupled receptor family (GPCR) [61, 62]. The C3a and $\mathrm{C} 5 \mathrm{a}$ receptors are part of a subgroup of receptors that includes the $\mathrm{N}$-formyl-methionyl receptors and several related orphan receptors. There is no indication that any of the orphan GPCR serves as a C4a receptor. In fact, the branching pattern and evolutionary distance argues against $\mathrm{C} 4 \mathrm{a}$ as a ligand for these receptors [62]. Could C4a bind and signal through other GPCR family members outside the complement anaphylatoxin and FMLP subgroup, particularly within the peptide receptor subgroupings? It seems unlikely since many of these receptors bind small molecules such as nucleotides, lipids, biogenic amines, cyclic peptides, and glutamate. Of the remaining peptide receptor subgroups, most of the members bind smaller peptides with conformational features markedly different from that of C4a [62].

The complement anaphylatoxin receptors bind their respective ligands with a low nanomolar affinity $[30,31$, 58], with the exception of no binding between C3adesArg and the $\mathrm{C} 3 \mathrm{aR}[63,64]$ and a low affinity binding between C5a-desArg and C5aR1 (see fig. 2). Neither C3a nor C5a serves as an effective agonist in cross-desensitization assays, a finding supported by studies mapping distinct 


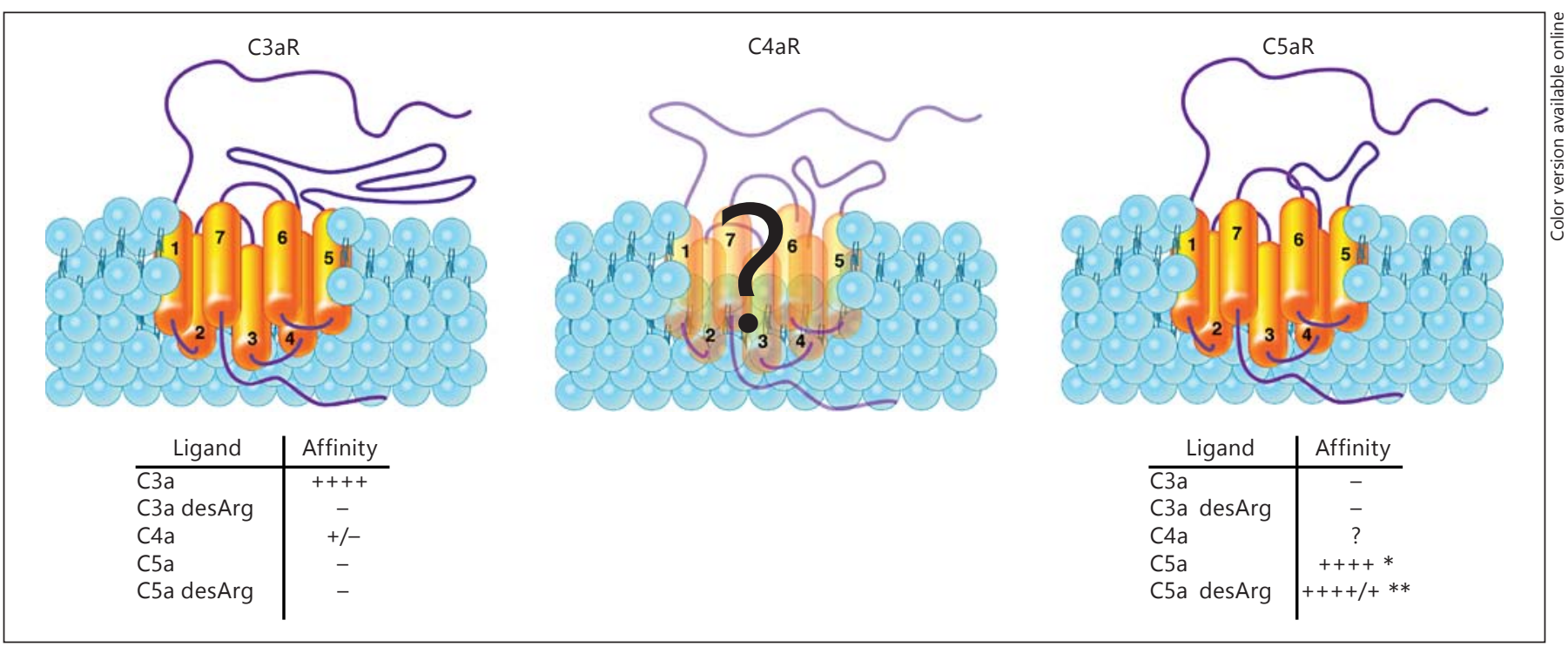

Fig. 2. Schematic of the human complement anaphylatoxin receptor structure. A schematic structure of the human C3a and C5 receptors is shown. Both receptors are G protein-coupled, 7-membrane-spanning family members. Each transmembrane domain is numbered. The C3aR is unique among GPCRs due to the unusually large extracellular loop between transmembrane domains 4

ligand:receptor binding sites for both peptides [65-70]. $\mathrm{C} 4 \mathrm{a}$ weakly binds the human $\mathrm{C} 3 \mathrm{aR}$ when present in micromolar amounts but does not induce calcium mobilization, indicating that a functional $\mathrm{C} 4 \mathrm{aR}$ must be distinct from the C3aR $[29,71]$. Interestingly, human C4a binds the guinea pig $\mathrm{C} 3 \mathrm{aR}$ and induces calcium mobilization in in vitro assays when used in micromolar amounts [71]. This latter finding raises evolutionary questions regarding $\mathrm{C} 4 \mathrm{a}$. Does $\mathrm{C} 4 \mathrm{a}$ in lower species preferentially signal through the $\mathrm{C} 3 \mathrm{a}$ or $\mathrm{C} 5 \mathrm{a}$ receptors? Perhaps signaling through the $\mathrm{C} 4 \mathrm{aR}$ was functionally redundant and the receptor was selected against over time. Studies designed to address these and other questions are feasible and may shed light on evolutionary divergence of the anaphylatoxin receptors and their ligand interactions.

\section{Conclusions and Perspectives}

The anaphylactic activity of complement was initially postulated over 100 years ago [72], and subsequent studies in passive cutaneous anaphylaxis directly demonstrated a role for complement but did not implicate the complement anaphylatoxins as we know them today $[73,74$, and 5 . The as yet unidentified C4a receptor is shown as partially transparent in the center panel. Shown below the $\mathrm{C} 3 \mathrm{aR}$ and $\mathrm{C} 5 \mathrm{aR}$ are the relative binding affinities for their known ligands. ${ }^{*}$ The affinity of $\mathrm{C} 5 \mathrm{a}$ for both $\mathrm{C} 5 \mathrm{aR}$ is in the low nanomolar range. ${ }^{* *}$ The affinity for C5a desArg for C5aR1 is in the low nanomolar range, while the affinity for $\mathrm{C} 5 \mathrm{aR} 2$ is in the micromolar range.

75]. In the late sixties, multiple groups independently documented the isolation and functional activity of C3a and C5a using purified complement proteins [76-78]. Since that time, C3a and C5a have been shown to contribute to a broad array of biological functions well beyond that of their classical role as anaphylatoxins inducing smooth muscle contraction, wheal and flare reactions, or platelet activation. Expression of the receptors for $\mathrm{C} 3 \mathrm{a}$ and $\mathrm{C} 5 \mathrm{a}$ on nearly all cells types provides broad support for these newly described biological activities [reviewed in 4]. From an evolutionary point of view, the C3a and C5a receptors have integrated anaphylatoxin-mediated control of adaptive immune responses at the level of the bony fishes since these receptors have been conserved in teleost fish for over 300 million years $[79,80]$. The control of other biological functions by C3a and C5a in organisms phylogenetically simpler than the teleost fish remains to be established. In contrast, C4a appears to be the dunsel of the complement anaphylatoxin family. It fails to meet the minimum expectations for a classic complement anaphylatoxin and has yet to be shown to contribute to adaptive immune responses or any of the more recently described developmental or regenerative activities of C3a and C5a. The absence of a C4a receptor, coupled with the inability to bind and signal effectively through 
the $\mathrm{C} 3 \mathrm{aR}$ and $\mathrm{C} 5 \mathrm{aR}$, suggests that the primary function of $\mathrm{C} 4 \mathrm{a}$ is to serve as the 'pro' portion of $\mathrm{C} 4$, stabilizing $\mathrm{C} 4$ and its thioester bond until the classical or lectin pathways are activated. Until C4a is shown to contribute to immune responses, it should not be considered an anaphylatoxin and, as suggested by Klos et al. [4] it may make more sense to eliminate the term anaphylatoxin altogether given their broad functional array.

\section{Acknowledgements}

The author thanks David Fisher for the anaphylatoxin receptor illustration and Dr. Robert Ames for critical reading of this paper.

\section{Disclosure Statement}

The author declares no competing interests.

\section{References}

1 Rutkowski MJ, Sughrue ME, Kane AJ, Ahn BJ, 12 Ohinata K, Yoshikawa M: Food intake regulaFang S, Parsa AT: The complement cascade as a mediator of tissue growth and regeneration. Inflamm Res 2010;59:897-905.

2 Rutkowski MJ, Sughrue ME, Kane AJ, Mills SA, Fang S, Parsa AT: Complement and the central nervous system: emerging roles in development, protection and regeneration. Immunol Cell Biol 2010;88:781-786.

- 3 Klos A, Tenner AJ, Johswich KO, Ager RR, Reis ES, Kohl J: The role of the anaphylatoxins in health and disease. Mol Immunol 2009;46: 2753-2766.

-4 Klos A, Wende E, Wareham KJ, Monk PN: International union of basic and clinical pharmacology. LXXXVII. Complement peptide c5a, c4a, and c3a receptors. Pharmacol Rev 2013;65:500-543.

5 Kimura Y, Madhavan M, Call MK, Santiago W, Tsonis PA, Lambris JD, Del Rio-Tsonis K: Expression of complement 3 and complement 5 in newt limb and lens regeneration. J Immunol 2003;170:2331-2339.

6 Stephan AH, Barres BA, Stevens B: The complement system: an unexpected role in synaptic pruning during development and disease. Annu Rev Neurosci 2012;35:369-389.

7 Schupf N, Williams CA, Hugli TE, Cox J: Psychopharmacological activity of anaphylatoxin C3a in rat hypothalamus. J Neuroimmunol 1983;5:305-316.

-8 Williams CA, Schupf N, Hugli TE: Anaphylatoxin C5a modulation of an alpha-adrenergic receptor system in the rat hypothalamus. J Neuroimmunol 1985;9:29-40.

-9 Schupf N, Williams CA, Berkman A, Cattell WS, Kerper L: Binding specificity and presynaptic action of anaphylatoxin C5a in rat brain. Brain Behav Immun 1989;3:28-38.

-10 Ohinata K, Inui A, Asakawa A, Wada K, Wada E, Yoshikawa M: Albutensin A and complement C3a decrease food intake in mice. Peptides 2002;23:127-133.

$\checkmark 11$ Ohinata K, Takagi K, Biyajima K, Kaneko K, Miyamoto C, Asakawa A, Eguchi N, Urade Y, Inui A, Yoshikawa M: Complement C5a stimulates food intake via a prostaglandin $\mathrm{D}(2)$ and neuropeptide Y-dependent mechanism in mice. Prostaglandins Other Lipid Mediat 2009;90:81-84. tion by central complement system. Adv Exp Med Biol 2008;632:35-46.

$\checkmark 13$ Ember JA, Jagels MA, Hugli TE: Characterization of complement anaphylatoxina and their biological responses; in Volanakis JE, Frank MM (eds): The Human Complement System in Health and Disease. New York, Dekker, 1998, pp 241-284.

14 Fernandez HN, Hugli TE: Primary structural analysis of the polypeptide portion of human c5a anaphylatoxin: polypeptide sequence determination and assignment of the oligosaccharide attachment site in C5a. J Biol Chem 1978;253:6955-6964.

15 Nettesheim DG, Edalji RP, Mollison KW, Greer J, Zuiderweg ER: Secondary structure of complement component C3a anaphylatoxin in solution as determined by NMR spectroscopy: differences between crystal and solution conformations. Proc Natl Acad Sci U S A 1988;85:5036-5040.

16 Zhang X, Boyar W, Toth MJ, Wennogle L, Gonnella NC: Structural definition of the C5a $\mathrm{C}$ terminus by two-dimensional nuclear magnetic resonance spectroscopy. Proteins 1997; 28:261-267.

17 Zuiderweg ER, Nettesheim DG, Mollison KW, Carter GW: Tertiary structure of human complement component $\mathrm{C} 5 \mathrm{a}$ in solution from nuclear magnetic resonance data. Biochemistry 1989;28:172-185.

18 Hugli TE: Human anaphylatoxin (C3a) from the third component of complement: primary structure. J Biol Chem 1975;250:82938301.

19 Moon KE, Gorski JP, Hugli TE: Complete primary structure of human C4a anaphylatoxin. J Biol Chem 1981;256:8685-8692.

20 Hugli TE, Vallota EH, Muller-Eberhard HJ: Purification and partial characterization of human and porcine C3a anaphylatoxin. J Biol Chem 1975;250:1472-1478.

21 Smith MA, Gerrie LM, Dunbar B, Fothergill JE: Primary structure of bovine complement activation fragment $\mathrm{C} 4 \mathrm{a}$, the third anaphylatoxin: purification and complete amino acid sequence. Biochem 1982;207:253-260.

22 Cui L, Carney DF, Hugli TE: Primary structure and functional characterization of rat
C5a: an anaphylatoxin with unusually high potency. Protein Sci 1994;3:1169-1177.

23 Wetsel RA, Lemons RS, Le Beau MM, Barnum SR, Noack D, Tack BF: Molecular analysis of human complement component C5: localization of the structural gene to chromosome 9. Biochemistry 1988;27:1474-1482.

24 Huber R, Scholze H, Paques EP, Deisenhofer $\mathrm{J}$ : Crystal structure analysis and molecular model of human C3a anaphylatoxin. Hoppe Seylers Z Physiol Chem 1980;361:1389-1399.

25 Paques EP, Scholze H, Huber R: Purification and crystallization of human anaphylatoxin, C3a. Hoppe Seylers Z Physiol Chem 1980; 361:977-980.

26 Greer J: Comparative structural anatomy of the complement anaphylatoxin proteins C3a, C4a and C5a. Enzyme 1986;36:150-163.

27 Pasupuleti M, Walse B, Nordahl EA, Morgelin M, Malmsten M, Schmidtchen A: Preservation of antimicrobial properties of complement peptide C3a, from invertebrates to humans. J Biol Chem 2007;282:2520-2528.

28 Fredslund F, Laursen NS, Roversi P, Jenner L, Oliveira CL, Pedersen JS, Nunn MA, Lea SM, Discipio R, Sottrup-Jensen L, Andersen GR: Structure of and influence of a tick complement inhibitor on human complement component 5. Nat Immunol 2008;9:753-760.

29 Ames RS, Tornetta MA, Foley JJ, Hugli TE, Sarau HM: Evidence that the receptor for C4a is distinct from the C3a receptor. Immunopharmacology 1997;38:87-92.

30 Ames RS, Li Y, Sarau HM, Nuthulaganti P, Foley JJ, Ellis C, Zeng Z, Su K, Jurewicz AJ, Hertzberg RP, Bergsma DJ, Kumar C: Molecular cloning and characterization of the human anaphylatoxin C3a receptor. J Biol Chem 1996;271:20231-20234.

31 Crass T, Raffetseder U, Martin U, Grove M, Klos A, Kohl J, Bautsch W: Expression cloning of the human $\mathrm{C} 3 \mathrm{a}$ anaphylatoxin receptor (C3aR) from differentiated U-937 cells. Eur J Immunol 1996;26:1944-1950.

32 Tsuruta T, Yamamoto T, Matsubara S, Nagasawa S, Tanase S, Tanaka J, Takagi K, Kambara T: Novel function of C4a anaphylatoxin: release from monocytes of protein which inhibits monocyte chemotaxis. Am J Pathol 1993;142:1848-1857. 
33 Kato Y, Nakao M, Shimizu M, Wariishi H, 46 Benard M, Raoult E, Vaudry D, Leprince J, Yano T: Purification and functional assessment of c3a, c4a and c5a of the common carp (Cyprinus carpio) complement. Dev Comp Immunol 2004;28:901-910.

>34 Gorski JP, Hugli TE, Muller-Eberhard HJ: C4a: The third anaphylatoxin of the human complement system. Proc Natl Acad Sci U S A 1979;76:5299-5302.

-35 Hugli TE, Kawahara MS, Unson CG, Molinar-Rode R, Erickson BW: The active site of human C4a anaphylatoxin. Mol Immunol 1983;20:637-645.

-36 Fukuoka Y, Xia HZ, Sanchez-Munoz LB, Dellinger AL, Escribano L, Schwartz LB: Generation of anaphylatoxins by human beta-tryptase from C3, C4, and C5. J Immunol 2008;180: 6307-6316.

>37 Meuer S, Ecker U, Hadding U, Bitter-Suermann D: Platelet-serotonin release by $\mathrm{C} 3 \mathrm{a}$ and C5a: Two independent pathways of activation. J Immunol 1981;126:1506-1509.

>38 Meuer S, Hugli TE, Andreatta RH, Hadding U, Bitter-Suermann D: Comparative study on biological activities of various anaphylatoxins (C4a, C3a, C5a): investigations on their ability to induce platelet secretion. Inflammation 1981;5:263-273.

-39 Raedler H, Vieyra MB, Leisman S, Lakhani P, Kwan W, Yang M, Johnson K, Faas SJ, Tamburini P, Heeger PS: Anti-complement component $\mathrm{C} 5 \mathrm{mAB}$ synergizes with CTLA4Ig to inhibit alloreactive $\mathrm{T}$ cells and prolong cardiac allograft survival in mice. Am J Transplant 2011;11:1397-1406.

-40 Vieyra M, Leisman S, Raedler H, Kwan WH, Yang M, Strainic MG, Medof ME, Heeger PS: Complement regulates CD4 T-cell help to CD8 T cells required for murine allograft rejection. Am J Pathol 2011;179:766-774.

-41 Lalli PN, Strainic MG, Yang M, Lin F, Medof ME, Heeger PS: Locally produced C5a binds to $\mathrm{T}$ cell-expressed C5aR to enhance effector $\mathrm{T}$-cell expansion by limiting antigen-induced apoptosis. Blood 2008;112:1759-1766.

-42 Liu J, Lin F, Strainic MG, An F, Miller RH, Altuntas CZ, Heeger PS, Tuohy VK, Medof ME: IFN-gamma and IL-17 production in experimental autoimmune encephalomyelitis depends on local APC-T cell complement production. J Immunol 2008; 180:5882-5889.

-43 Strainic MG, Liu J, Huang D, An F, Lalli PN, Muqim N, Shapiro VS, Dubyak GR, Heeger PS, Medof ME: Locally produced complement fragments $\mathrm{C} 5 \mathrm{a}$ and $\mathrm{C} 3 \mathrm{a}$ provide both costimulatory and survival signals to naive CD4+ T cells. Immunity 2008;28:425-435.

44 Han G, Geng S, Li Y, Chen G, Wang R, Li X, Ma Y, Shen B, Li Y: GammadeltaT-cell function in sepsis is modulated by $\mathrm{C} 5$ a receptor signalling. Immunology 2011;133:340-349.

-45 Liu Z, Eltoum IE, Guo B, Beck BH, Cloud GA, Lopez RD: Protective immunosurveillance and therapeutic antitumor activity of gammadelta $\mathrm{T}$ cells demonstrated in a mouse model of prostate cancer. J Immunol 2008; 180:6044-6053.
Falluel-Morel A, Gonzalez BJ, Galas L, Vaudry H, Fontaine M: Role of complement anaphylatoxin receptors $(\mathrm{C} 3 \mathrm{aR}, \mathrm{C} 5 \mathrm{aR})$ in the development of the rat cerebellum. Mol Immunol 2008;45:3767-3774.

47 Shinjyo N, Stahlberg A, Dragunow M, Pekny M, Pekna M: Complement-derived anaphylatoxin $\mathrm{C} 3 \mathrm{a}$ regulates in vitro differentiation and migration of neural progenitor cells. Stem Cells 2009;27:2824-2832.

48 Carmona-Fontaine C, Theveneau E, Tzekou A, Tada M, Woods M, Page KM, Parsons M, Lambris JD, Mayor R: Complement fragment C3a controls mutual cell attraction during collective cell migration. Dev Cell 2011;21 1026-1037.

49 Jalili A, Shirvaikar N, Marquez-Curtis L, Qiu Y, Korol C, Lee H, Turner AR, Ratajczak MZ, Janowska-Wieczorek A: Fifth complement cascade protein (C5) cleavage fragments disrupt the SDF-1/CXCR4 axis: further evidence that innate immunity orchestrates the mobilization of hematopoietic stem/progenitor cells. Exp Hematol 2010;38:321-332.

50 Strey CW, Markiewski M, Mastellos D, Tudoran R, Spruce LA, Greenbaum LE, Lambris JD: The proinflammatory mediators C3a and C5a are essential for liver regeneration. J Exp Med 2003;198:913-923.

51 Haynes T, Luz-Madrigal A, Reis ES, Echeverri Ruiz NP, Grajales-Esquivel E, Tzekou A, Tsonis PA, Lambris JD, Del Rio-Tsonis K: Complement anaphylatoxin $\mathrm{C} 3 \mathrm{a}$ is a potent inducer of embryonic chick retina regeneration. Nat Commun 2013;4:2312.

52 Malmsten M, Davoudi M, Walse B, Rydengard V, Pasupuleti M, Morgelin M, Schmidtchen A: Antimicrobial peptides derived from growth factors. Growth Factors 2007;25:60-70.

53 Nordahl EA, Rydengard V, Nyberg P, Nitsche DP, Morgelin M, Malmsten M, Bjorck L, Schmidtchen A: Activation of the complement system generates antibacterial peptides. Proc Natl Acad Sci U S A 2004;101:1687916884.

54 Gao Z, Li M, Wu J, Zhang S: Interplay between invertebrate $\mathrm{C} 3 \mathrm{a}$ with vertebrate mac rophages: functional characterization of immune activities of amphioxus C3a. Fish Shellfish Immunol 2013;35:1249-1259.

55 Zhao Y, Xu H, Yu W, Xie BD: Complement anaphylatoxin $\mathrm{C} 4 \mathrm{a}$ inhibits $\mathrm{C} 5 \mathrm{a}$-induced neointima formation following arterial injury. Mol Med Rep 2014;10:45-52.

56 Murakami Y, Yamamoto T, Imamichi T, Nagasawa $\mathrm{S}$ : Cellular responses of guinea-pig macrophages to $\mathrm{C} 4 \mathrm{a}$ : inhibition of $\mathrm{C} 3 \mathrm{a}-\mathrm{in}$ duced $\mathrm{O}_{2}$ - generation by $\mathrm{C} 4 \mathrm{a}$. Immunol Lett 1993;36:301-304.

57 Yount NY, Bayer AS, Xiong YQ, Yeaman MR: Advances in antimicrobial peptide immunobiology. Biopolymers 2006;84:435-458.

58 Gerard NP, Gerard C: The chemotactic receptor for human C5a anaphylatoxin. Nature 1991;349:614-617.
59 Roglic A, Prossnitz ER, Cavanagh SL, Pan Z, Zou A, Ye RD: cDNA cloning of a novel G protein-coupled receptor with a large extracellular loop structure. Biochim Biophys Acta 1996;1305:39-43.

60 Ohno M, Hirata T, Enomoto M, Araki T, Ishimaru H, Takahashi TA: A putative chemoattractant receptor, C5L2, is expressed in granulocyte and immature dendritic cells, but not in mature dendritic cells. Mol Immunol 2000; 37:407-412.

61 Rosenbaum DM, Rasmussen SG, Kobilka BK: The structure and function of G-proteincoupled receptors. Nature 2009;459:356363.

62 Joost P, Methner A: Phylogenetic analysis of 277 human G-protein-coupled receptors as a tool for the prediction of orphan receptor ligands. Genome Biol 2002;3:RESEARCH0063.

-63 Wilken HC, Gotze O, Werfel T, Zwirner J: $\mathrm{C} 3 \mathrm{a}$ (desArg) does not bind to and signal through the human $\mathrm{C} 3 \mathrm{a}$ receptor. Immunol Lett 1999;67:141-145.

64 Johswich K, Martin M, Thalmann J, Rheinheimer C, Monk PN, Klos A: Ligand specificity of the anaphylatoxin C5L2 receptor and its regulation on myeloid and epithelial cell lines. J Biol Chem 2006;281:39088-39095.

-65 Crass T, Ames RS, Sarau HM, Tornetta MA, Foley JJ, Kohl J, Klos A, Bautsch W: Chimeric receptors of the human $\mathrm{C} 3$ a receptor and $\mathrm{C} 5 \mathrm{a}$ receptor (CD88). J Biol Chem 1999;274: 8367-8370.

66 Chao TH, Ember JA, Wang M, Bayon Y, Hugli TE, Ye RD: Role of the second extracellular loop of human C3a receptor in agonist binding and receptor function. J Biol Chem 1999; 274:9721-9728.

67 Sun J, Ember JA, Chao TH, Fukuoka Y, Ye RD, Hugli TE: Identification of ligand effector binding sites in transmembrane regions of the human G protein-coupled C3a receptor. Protein Sci 1999;8:2304-2311

68 Nikiforovich GV, Baranski TJ: Structural mechanisms of constitutive activation in the C5a receptors with mutations in the extracellular loops: molecular modeling study. Proteins 2012;80:71-80.

-69 Nikiforovich GV, Marshall GR, Baranski TJ: Modeling molecular mechanisms of binding of the anaphylatoxin $\mathrm{C} 5 \mathrm{a}$ to the $\mathrm{C} 5 \mathrm{a}$ receptor. Biochemistry 2008;47:3117-3130.

70 Nikiforovich GV, Marshall GR, Baranski TJ: Simplified modeling approach suggests structural mechanisms for constitutive activation of the C5a receptor. Proteins 2011;79:787802 .

71 Lienenklaus S, Ames RS, Tornetta MA, Sarau HM, Foley JJ, Crass T, Sohns B, Raffetseder U, Grove M, Holzer A, Klos A, Kohl J, Bautsch W: Human anaphylatoxin $\mathrm{C} 4 \mathrm{a}$ is a potent agonist of the guinea pig but not the human C3a receptor. J Immunol 1998;161: 2089-2093.

72 Zinsser H: On anaphylatoxins and endotoxins of the typhoid bacillus. J Exp Med 1913;17: $117-131$. 
73 Schwab L, Moll FC, Hall T, Brean H, Kirk M, van Zandt Hawn C, Janeway CA: Experimental hypersensitivity in the rabbit: effect of inhibition of antibody formation by X-radiation and nitrogen mustards on the histologic and serologic sequences, and on the behavior of serum complement, following single large injections of foreign proteins. J Exp Med 1950; 91:505-526.

74 Osler AG, Hawrisiak MM, Ovary Z, Siqueira M, Bier OG: Studies on the mechanism of hypersensitivity phenomena. 2 . The participation of complement in passive cutaneous anaphylaxis of the albino rat. J Exp Med 1957;106: 811-834.
5 Osler AG, Randall HG, Hill BM, Ovary Z: Studies on the mechanism of hypersensitivity phenomena. 3. The participation of complement in the formation of anaphylatoxin. J Exp Med 1959;110:311-339.

76 Jensen J: Anaphylatoxin in its relation to the complement system. Science 1967;155:11221123.

77 da Silva WD, Eisele JW, Lepow IH: Complement as a mediator of inflammation. 3. Purification of the activity with anaphylatoxin properties generated by interaction of the first four components of complement and its identification as a cleavage product of C'3. J Exp Med 1967;126:1027-1048
78 Cochrane CG, Muller-Eberhard HJ: The derivation of two distinct anaphylatoxin activities from the third and fifth components of human complement. J Exp Med 1968;127: 371-386.

79 Boshra H, Wang T, Hove-Madsen L, Hansen J, Li J, Matlapudi A, Secombes CJ, Tort L, Sunyer JO: Characterization of a C3a receptor in rainbow trout and Xenopus: the first identification of $\mathrm{C} 3 \mathrm{a}$ receptors in nonmammalian species. J Immunol 2005;175:2427-2437.

80 Sunyer JO, Boshra H, Li J: Evolution of anaphylatoxins, their diversity and novel roles in innate immunity: insights from the study of fish complement. Vet Immunol Immunopathol 2005;108:77-89. 